\title{
INSTAGRAM SEBAGAI MEDIA PROMOSI FESTIVAL PARIWISATA KOTA BOGOR (STUDI ETNOGRAFI VIRTUAL PADA AKUN @ cgmbogor_fest)
}

\author{
Aprilianti Pratiwi dan M. Girindra Madanacaragni \\ Universitas Pancasila \\ aprilyantipratiwi@univpancasila.ac.id
}

\begin{abstract}
Abstrak
Perkembangan teknologi telah mengubah proses komunikasi, tak terkecuali pada aspek promosi. Proses promosi yang semula banyak dilakukan secara tatap muka kini telah dimediasi dengan media komputer atau biasa disebut dengan CMC (Computer Mediated Communication). Tujuan penelitian ini adalah untuk mengidentifikasi bentuk promosi Cap Go Meh Bogor Street Festival yang dilakukan oleh akun Instagram @ cgmbogor_fest. Metode yang digunakan pada penelitian ini adalah etnografi virtual. Melalui metode observasi mendalam secara virtual yang telah dilakukan, diketahui bahwa panitia Cap Go M eh Bogor Street Festival melakukan promosi pariwisata melalui akun @cgmbogor_fest dengan mengunggah poster digital, poto, video dan potongan poto. - Dari keempat bentuk promosi digital pada akun @ cgmbogor_fest, poster menjadi alat promosi utama karena dalam poster terdapat beberapa informasi, diantaranya tentang waktu dan tempat pelaksanaan festival, pengisi acara, nomor kontak yang dapat dihubungi serta media sosial yang dapat ditelusuri. Penggunaan media sosial menjadi salah satu media yang seringkali digunakan untuk promosi pariwisata dikarenakan dapat meningkatkan awareness masyarakat untuk dapat hadir ke suatu tempat secara nyata dengan bantuan informasi dari dunia maya.
\end{abstract}

Kata Kunci: CMC, etnografi virtual, instagram, promosi pariwisata, social media marketing

\begin{abstract}
Technological developments have changed the communication process, including the promotion aspect. The promotion process, which was previously done faceto-face, has now been mediated by computer or commonly known as CMC (Computer Mediated Communication). The purpose of this study was to identify the form of the Bogor Street Festival Cap Go Meh promotion carried out by the Instagram account @ cgmbogor_fest. The method used in this research is virtual ethnography. Through a virtual in-depth observation method that has been carried out, it is known that the committee of the Cap Go Meh Bogor Street Festival promotes tourism through the @ cgmbogor_fest account by uploading digital posters, photos, videos and photo grid. Of the four forms of digital
\end{abstract}


promotion on the @cgmbogor_fest account, digital poster is the main promotional tool because in the poster there is some information, including the time and place of the festival, the performers, contact numbers and contactable social media. The use of social media is one of the media that is often used for tourism promotion because it can increase public awareness to be able to present a real place with the help of information from cyberspace.

Keywords: CM C, instagram, social media marketing, tourism promotion, virtual etnography

\section{Pendahuluan}

Indonesia merupakan salah satu negara di dunia yang memiliki banyak potensi pariwisata, diantaranya keindahan alam yang beraneka ragam, kebudayaan yang unik dan beragam, serta situs peninggalan sejarah. Hal ini mengakibatkan pariwisata Indonesia diperhatikan oleh masyarakat dunia. Berdasarkan data The Travel \& Tourism Competitiveness Index (TTCl) pada tahun 2017 yang dikeluarkan oleh World Economic Forum (WEF), Indonesia berada di peringkat 42 dunia dalam indeks daya saing wisata. Indonesia mengungguli Rusia yang berada tepat satu peringkat di bawahnya, yaitu peringkat 43. Penilaian indeks ini diukur dari mudahnya lingkungan bisnis kepariwisataan, mudahnya prosedur untuk melakukan kegiatan pariwisata, ketersediaan infrastruktur, serta sumber daya alam dan budaya pariwisata yang ada (bersabda.com).

Pariwisata Indonesia patut diandalkan, terlebih sektor Pariwisata menjadi penyumbang devisa nomor 2 di Indonesia mengalahkan sektor minyak bumi dan gas (data Kementrian Pariwisata RI 2017). Capaian ini patut dibanggakan dan disyukuri oleh masyarakat Indonesia sehingga pariwisata Indonesia semakin dikenal baik dalam skala lokal hingga dunia. Pemerintahan pusat melalui Kementrian Pariwisata dan Industri Kreatif telah mempromosikan Indonesia ke kancah internasional dengan label "Wonderful Indonesia".

Ada beragam cara yang dilakukan untuk mendorong sektor pariwisata, diantaranya dengan melakukan promosi melalui media konvensional (iklan di televisi dan radio), media luar ruangan (brosur) dan melalui pameran. Proses 
promosi yang semula banyak dilakukan secara tatap muka kini telah dimediasi dengan media komputer atau biasa disebut dengan CMC (Computer Mediated Communication) (Ri'aeni 2015; dan Nurrahman \& Yuliati 2019). Media sosial terbukti memiliki dampak yang signifikan dalam meningkatkan angka pariwisata (Fatani dan Suyadnya 2015).

Salah satu media sosial yang banyak digunakan untuk promosi pariwisata adalah Instagram (Atiko et al. 2016; Sukoco 2017; Satvikadewi \& Hamim 2018; Purnomo 2018; Trihayuningtyas et al. 2018, Fauziah et al. 2018). Kurniawati (2016) menyatakan bahwa Instagram dipilih untuk menyebarkan informasi mengenai potensi wisata dikarenakan memiliki banyak keunggulan dan memberikan sejumlah keuntungan. Instagram sendiri memiliki kelebihan dalam aspek visual yang mana penggunanya dapat membagikan foto dan video dengan mudah dengan pengguna lainnya (Ting, 2014). Hal ini sejalan dengan spesialisasi yang dimiliki oleh Instagram yaitu sosial media yang khusus menampilkan gambar visual. Proses visualisasi yang terjadi dalam sosial media dapat meciptkakan suatu persepsi atau tanggapan bagi para pengguna yang melihat sehingga tercipta citra yang positif atau pun negatif (Kertamukti 2015).

Berdasarkan data survei yang dilakukan salah satu lembaga survei di Amerika Serikat pada tahun 2019 diketahui bahwa Instagram menempati posisi pertama sebagai platform media sosial paling popular yang digunakan untuk beriklan. Survei ini dilakukan terhadap 4.800 orang dari seluruh dunia dengan mayoritas responden berasal dari usaha mikro, yaitu sebanyak $60 \%$. Berdasarkan hasil survei ini diketahui bahwa adanya kecenderungan pergeseran dari Facebook ke Instagram dalam hal promosi. Masyarakat lebih tertarik untuk mempelajari mengenai Instagram diakibatkan oleh adanya penurunan penggunaan Facebook dan meningkatnya jumlah pengguna Instagram. 


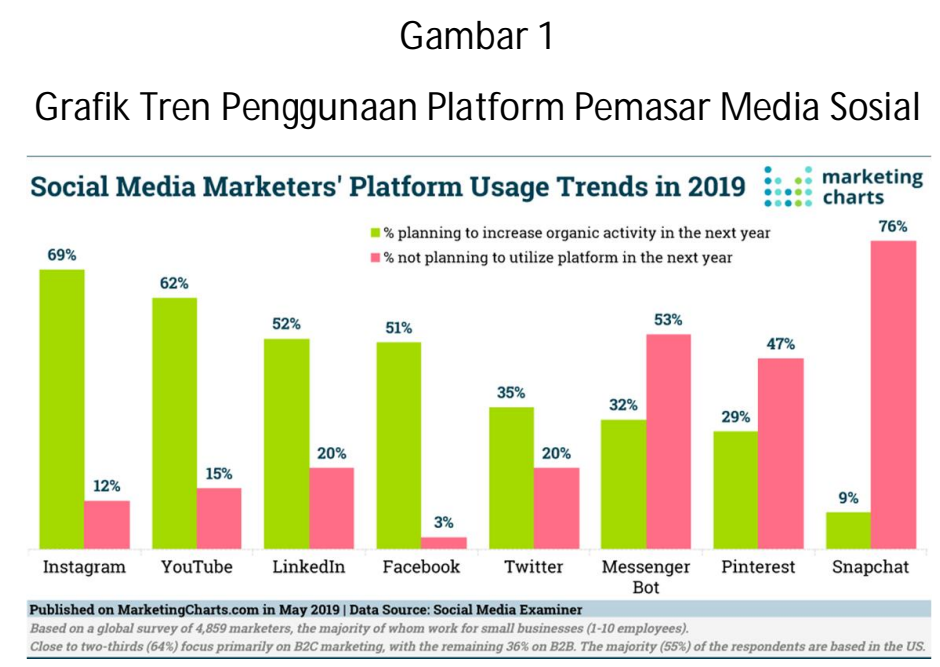

Sumber: https://www.marketingcharts.com/digital/social-media-108463

Media sosial, khususnya Instagram, dapat digunakan untuk berbagi pengalaman berwisata bagi wisatawan ataupun juga dapat dipergunakan soleh wisatawan sebagai sumber informasi untuk mencari tempat tujuan berwisata. Media sosial mudah dalam penggunaannya serta murah dari segi pembiayaan. Hal inilah yang menjadi penyebab banyaknya pihak yang menggunakan media sosial sebagai media promosi pariwisata (Gohil, 2015).

Salah satu pihak yang memanfaatkan Instagram sebagai media promosi pariwisata adalah panitia CGM Bogor Fest melalui akun @ cgmbogor_fest. Akun @cgmbogor_fest merupakan salah satu akun Instagram yang dibuat untuk mempromosikan acara pesta rakyat Cap Go Meh yang rutin dilaksanakan setiap tahun di Jalan Surya Kencana, Kota Bogor. Cap Go Meh merupakan salah satu perayaan yang dimiliki oleh etnis Tionghoa. Perayaan ini biasanya dilaksanakan pada hari kelima belas bulan pertama berdasarkan kalender Tiongkok. Di Bogor, perayaan ini menjadi unik karena tidak hanya dirayakan oleh etnis Tionghoa saja, akan tetapi menjadi ajang lintas budaya berbagai etnis yang ada di Kota Bogor. Kegiatan ini dikoordinir oleh masyarakat yang memiliki latar belakang suku, ras, agama dan golongan yang beragam. Hal ini sesuai dengan tema yang dimiliki dalam kegiatan ini yaitu "Ajang Budaya Pemersatu Bangsa”. 
M enurut M enteri Pariwisata, Whisnutama, festival ini merupakan salah satu cara yang efektif untuk meningkatkan kunjungan wisatawan yang datang ke Kota Bogor. Seperti yang kita ketahui bahwa selama ini dikenal sebagai tempat dengan surge wisata kuliner, keindahan alam dan tempat-tempat bersejarah. Kota Bogor kini memiliki festival yang mempertujukkan keanekaragaman budaya kepada wisatawan, baik domestic maupun mancanegara.

Terdapat sejumlah penelitian terdahulu yang mengkaji mengenai pemanfaatan Instagram sebagai media promosi pariwisata. Berdasarkan telaahan yang dilakukan, rata-rata penelitian terdahulu tersebut menggunakan metode kualitatif deskriptif Atiko et al. 2016; Sukoco 2017; Purnomo 2018; Fauziah et al. 2018, Nurjanah 2018; Satvikadewi \& Hamim 2018; Retnasary et al. 2019. Terdapat pula penelitian lainnya yang menggunakan pendekatan kuantitiatif diantaranya Trihayuningtyas et al. 2018. Belum ditemukan penggunaan metode etnografi virtual dalam mengkaji akun Instagram sebagai media promosi pariwisata. Sejauh ini penelitian komunikasi yang menggunakan etnografi virtual sebagai metode penelitian yaitu penelitian yang dilakukan oleh Santoso 2014; Prastika 2017; dan Pratiwi, et.al 2019; yang meneliti gerakan sosial melalui media sosial serta, penelitian yang dilakukan Wati \& Setiawan (2019) mengenai presentasi diri content creator di Instagram, serta penelitian yang dilakukan oleh Witri \& Pratiwi (2019) tentang komunikasi interpersonal pada lama Instagram Story. Oleh sebab itu penelitian ini dilakukan dengan menawarkan pendekatan etnografi virtual untuk memberikan penjelasan lebih rinci lagi mengenai interaksi manusia yang terjadi di dalam dunia digital berkaitan dengan promosi pariwisata.

\section{Tujuan Penelitian}

Tujuan penelitian ini adalah untuk mengidentifikasi bentuk promosi Cap Go Meh Bogor Street Festival yang dilakukan oleh akun Instagram @cgmbogor_fest. 


\section{Kerangka Teori dan Konsep}

\subsection{Teori Computer M ediated Communication (CMC)}

McQuail (2005) menyatakan bahwa Computer Mediated Communication (CMC) adalah komunikasi yang terjadi diantara dua individu atau lebih yang dimediasi oleh komputer. Berdasarkan pernyataan McQuail mengenai CMC tersebut dapat disimpulkan bahwa terjadi perubahan bentuk komunikasi yang terjadi diantara individu atau kelompok. Bentuk komunikasi yang tadinya dilakukan secara tatap muka, maka seiring perkembangan teknologi, komunikasi dilakukan dengan dimediasi oleh perangkat komputer tanpa melakukan tatap muka.

Tidak hanya komputer yang menjadi medium komunikasi dalam ruang lingkup CMC. Perangkat lain seperti laptop, telpon pintar, tablet dan jenis perangkat lainnya juga merupakan medium dalam teori ini. Dijelaskan oleh Rice (dikutip dari Budiargo 2015) bahwa teknologi yang dipergunakan dalam CM C, yang dimediasi oleh perangkat komputer telah memberikan fasilitas bagi terjadinya pertukaran pesan antara satu individu dengan individu lainnya.

Pada awal mula kemunculannya, teori ini digunakan untuk riset militer mengenai pertahanan dan akademik domain (Hiltz \& Turoff 1978). Perkembangan teknologi juga memperluas bidang kajian teori ini. Kini bentuk CM C menjadikan kita untuk melakukan komunikasi dengan bantuan perangkat berbasis komputer yang dibantu jaringan internet serta berbagai macam aplikasi. Dampak dari semua itu adalah kita dapat bermain game, membaca berita online, melakukan kegiatan jual-beli, bercakap-cakap dan lainnya (Arnus 2015). Kegiatan lain yang dapat kita lakukan dengan dimediasi oleh komputer adalah promosi pariwisata (Ri'aeni 2015; dan Nurahman \& Yuliati 2019). 


\subsection{Komunikasi dan Pariwisata}

\subsubsection{Definisi Komunikasi}

Sebelum mendefinisikan Komunikasi Pariwisata, ada baiknya kita definisikan komunikasi terlebih dahulu. Terdapat banyak definisi yang diberikan para ahli komunikasi untuk komunikasi. Masing-masing definisi berkaitan dengan bidang kajian para ahli tersebut. Berikut merupakan definisi komunikasi yang sudut pandang yang lebih luas.

Kincaid menjelaskan bahwa komunikasi merupakan sebuah proses antara dua orang atau lebih yang satu sama lain melakukan pertukaran informasi dengan harapan terjadinya saling pengertian. Selanjutnya Rogers mendefinisikan komunikasi sebagai sebuah kegiatan pertukaran pesan yang dilakukan oleh peserta komunikasi, yang mana salah satu pihak mengalami perubahan sikap dan tingkah laku serta kebersamaan. Shannon dan Weaver mendefinisikan komunikasi sebagai sebuah bentuk interaksi yang dilakukan manusia dalam rangka saling memengaruhi sat sama lain, baik disengaja ataupun tidak disengaja. Berdasarkan definisi Shannon dan Weaver ini, komunikasi yang dilakukan dapat berupa bahasa verbal atau non verbal, baik melalui tatap muka maupun bermedia (Cangara 2016).

Berdasarkan definisi komunikasi yang dijelaskan oleh para pakar komunikasi tersebut dapat disimpulkan bahwa komunikasi merupakan suatu kegiatan pertukaran informasi yang dilakukan oleh dua orang atau lebih dalam rangka untuk mengubah perilaku peserta komunikasi lain agar sesuai dengan keinginnya melalui media atau pun secara langsung.

\subsubsection{Definisi Pariwisata}

Terdapat beberapa definisi pariwisata menurut para ahli pariwisata. Tourism Society in Britain (Pendit, 1999) mendefinisikan pariwisata sebagai sebuah kegiatan bepergian yang dilakukan orang untuk waktu yang tidak panjang ke beberapa tempat yang dituju yang berada di luar domisili dan tempat kerjanya 
sehari-hari. Adapun kegiatan yang dilakukan oleh orang yang melakukan kegiatan pariwisata meliputi kunjungan seharian atau darmawisata. Wahab (Yoeti, 1995) mendefinisikan pariwisata sebagai aktivitas yang dilakukan oleh orang dengan sadar yang menerima pelayanan baik di dalam negeri maupun di luar negeri dalam jangka waktu sementara dengan tujuan mencari kepuasan yang berbeda dari tempat asalnya. Burkart dan Malik (Soekadijo, 2000) mendefinisikan pariwisata sebagai pindahnya seseorang dalam waktu yang tidak lama ke tempat tujuan di luar tempat ia tinggal dan bekerja.

Berdasarkan beberapa definisi dari ahli mengenai pariwisata tersebut dapat disimpulkan bahwa pariwisata merupakan kegiatan yang dilakukan oleh orang dalam jangka waktu yang pendek yang dilakukan secara sengaja dan terorganisir ke tempat yang berbeda dengan domisilinya dengan tujuan untuk mencari kesenangan.

\subsubsection{Komunikasi Pariwisata}

Berdasarkan definisi komunikasi dan pariwisata yang telah dikemukakan para ahli pada sub bab sebelumnya, dapat disimpulkan bahwa komunikasi pariwisata adalah proses penyampaian pesan atau informasi yang dilakukan oleh seseorang atau sebuah lembaga kepada orang lain mengenai perjalanan ke suau tempat atau suatu objek wisata. Bungin (2015) menjelaskan bahwa komunikasi berkontribusi dalam proses pemasaran dalam beberapa elemen pemasaran, utamanya berkontribusi dengan baik pada media dan konten komunikasi. Pada elemen media komunikasi terdapat bermacam-macam media komunikasi yang dapat dipergunakan sebagai media pemasaran, tempat tujuan wisata, keteraksesan (berkenaan dengan transportasi), sumber daya manusia dan lembaga pariwisata. Komunikasi memiliki peran dalam mempersiapkan isi pesan yang akan disampaikan kepada khalayak sasaran, dalam konteks ini adalah calon wisatawan, mengenai informasi yang sebaiknya mereka ketahui, diantaranya 
berbagai media pemasaran, tempat tujuan wisata, keteraksesan (berkenaan dengan transportasi), sumber daya manusia dan lembaga pariwisata.

Bungin (2015) menjelaskan bahwa komunikasi pariwisata mempunyai sejumlah aspek kajian utama yang bisa dikembangkan dan berkembang sesuai semakin luasnya bidang kajian ilmu komunikasi dan semakin perkembangan industri pariwisata, yaitu: komunikasi pemasaran pariwisata, brand destinasi, manajemen komunikasi pariwisata, komunikasi transportasi pariwisata, komunikasi visual pariwisata, komunikasi kelompok pariwisata, komunikasi online pariwisata, Public Relations dan MICE, serta riset komunikasi pariwisata. Berdasar kesembilan aspek kajian tersebut, penelitian ini hanya fokus pada aspek komunikasi online pariwisata, yaitu fokus pada akun Instagram.

\subsection{Instagram sebagai Media Promosi Pariwisata}

Instagram merupakan salah satu media berbagi yang memberikan fasilitas bagi para pengguna untuk berbagi dengan menggunakan media gambar/poto, video. Instagram memberikan kemudahan bagi para penggunanya untuk mengunggah poto atau video dengan tambahan caption (keterangan). Inilah yang menjadi salah satu penyebab digunakannya Instagram sebagai media promosi.

Terdapat lima fitur utama Instagram, yaitu home page, komentar, explore, profil, dan news feed (Atmoko, 2018). Terdapat pula beberapa fitur Instagram yang menambah makna dalam informasi yang terdapat pada poto atau video yang diunggah oleh pemilik akun Instagram, yaitu judul poto, hastag, dan geotag atau lokasi. Lalu terdapat pula sejumlah aktivitas yang dilakukan oleh para pengguna Instagram, yaitu follow (mengikuti), like (menyukai), komentar, dan mentions (Sugiarto, 2018).

Instagram kini dipilih sebagai media untuk melakukan promosi pariwisata. Hal ini dapat dilihat pada penelitian Araujo et al (2014) yang menemukan fakta bahwa terdapat $76,1 \%$ pengguna Instagram mengunggah poto tempat berwisata 
yang telah dikunjungi ke akun mereka. Kegiatan ini dapat dilihat dan menarik perhatian pengguna Instagram lain (followers) yang mengikuti akun tersebut yang pada tahap selanjutnya membuat followers berkeinginan untuk melakukan pengalaman wisata yang sama. Puncaknya followers merealisasikannya atau dengan kata lain berwisata juga ke tempat yang sama.

\section{Metode Penelitian}

Penelitian ini menggunakan metode etnografi virtual, yaitu metode yang dipergunakan guna menyelidiki masyarakat pengguna internet (Hine 2000). Metode ini juga dilakukan agar mampu memberikan gambaran secara teoritis bagaimana baiknya hubungan yang terjadi di dunia maya. Etnografi virtual digunakan untuk menjelaskan interaksi sosial masyarakat di dunia maya dan mendeskripsikan bagaimana manusia memberikan makna pada dunia sosial yang dimiliki dibarengi dengan kemajuan teknologi (Kozinets 2013). Pada metode etnografi virtual, data dikumpulkan dengan metode observasi berperan serta atau pasrtisipatif secara digital melalui dua prosedur, yaitu penyelidikan dan perincian.

\section{a. melakukan penyelidikan terhadap lingkungan yang diamati}

Penulis sudah melakukan proses pra-penulisan, atau pengumpulan data sebelum melakukan penelitian dengan tujuan untuk memahami lingkungan subjek atau objek penelitian. Berdasarkan data yang didapat pada saat prapenelitian, diketahui bahwa panitia penyelenggara Cap Go Meh Bogor Street Festival (CGMBSF) memiliki lima akun media sosial, yaitu website (capgomehbogor.com); Instagram (@cgmbogor_fest); Twitter (@cgmbogor_fest); Facebook (CGM - Bogor StreetFest); dan Youtube (CGM Bogor StreetFest).

Berdasarkan observasi virtual yang dilakukan, akun Instagram, Facebook dan Twitter milik CGMBSF sama-sama melakukan aktivitas pengunggahan terakhir 
pada 3 Juni 2020. Unggahan yang terdapat pada ketiga akun media sosial milik CGM BSF tersebut memiliki kesamaan konten, yaitu ucapan selamat untuk ulang tahun untuk kota Bogor. Akan tetapi dari ketiga akun tersebut, akun Instagram CGM BSF memiliki jumlah like paling banyak, yaitu sebanyak 142. Akun Facebook CGM BSF hanya mendapatkan 12 likes, bahkan akun Twitter-nya sama sekali tidak mendapatkan like. Masih berdasarkan data observasi virtual yang didapat, akun Instagram CGMBSF mendapat tanggapan berupa komentar dari pengikutnya. Akun Facebook dan akun Twitter milik CGMBSF sama sekali tidak terdapat komentar dari para pengikutnya. Akun Youtube milik CGMBSF terakhir menggunggah video pada 4 bulan lalu dengan judl 'Live Streaming CGM - Bogor StreetFest 2020 "LOOKING EASTWARD"'. Jumlah penonton yang menyaksikan unggahan video tersebut adalah 18.489 dengan tiga komentar.

Berdasarkan data observasi virtual yang didapat tersebut, penulis memilih akun Instagram CGMBFS untuk dijadikan lapangan penelitian karena akun tersebut lebih "hidup" jika dibandingkan dengan akun media sosial milik CGM BSF lainnya. Nasrullah (2018) menjelaskan bahwa etnografi komunikasi adalah gabungan bidang ilmu antropologi dan linguistik untuk mengkaji artefak percakapan yang terjadi antara manusia dalam suatu komuniktas yang fokus pada percakapan dan bahasa yang digunakan penutur. Semakin banyak interaksi dan pertukaran pesan yang terjadi pada akun Instagram milik CGM BSF semakin baik.

\section{b. Melakukan perincian terhadap lapangan penelitian}

Tahap selanjutnya adalah peneliti melakukan perincian terhadap akun Instagram @cgmbogor_fest yaitu dengan cara berinteraksi langsung dengan akun tersebut. Awalnya, peneliti menjadi pengikut (follower) akun tersebut. Kemudian peneliti melakukan pengamatan menyeluruh terhadap akun ini. Jumlah postingan yang terdapat pada akun Instagram @ cgmbogor_fest pada 26 Juni 2020 adalah sebanyak 365. Jumlah pengikutnya (followers) adalah 3.957, 
sedangkan jumlah yang diikuti (following) adalah 289. Akun @cgmbogor_fest mengikuti akun-akun resmi media, seniman, politikus (wali kota Bogor), tempat wisata dan masyarakat sipil. Akun yang mengikuti akun @ cgmbogor_fest adalah akun-akun masyarakat sipil, politikus, dan beberapa akun wisata serta toko online.

Akun @cgmbogor_fest pertama kali melakukan unggahan pada 13 Februari 2015 dengan mengunggah sebuah poto shio kambing yang bertuliskan 'CGM 2015, Ajang Budaya Bogor Pemersatu Bangsa'. Unggahan ini mendapatkan 17 likes tanpa komentar dari pengikut. Pada unggahan tahun pertama dan kedua (2015-2016) jumlah likes yang terdapat pada setiap postingan tidak lebih dari 100. Baru pada 2017 jumlah likes mulai di atas 100. Unggahan biasanya bertemakan promosi acara Cap Go M eh, poto-poto kegiatan festival Cap Go M eh di tahun sebelumnya, kegiatan buka bersama dan santunan anak yatim piatu, ucapan hari-hari besar seperti Hari Raya Imlek dan Hari Welas Asih serta ucapan ulang tahun kota Bogor. Banyaknya jumlah unggahan dan beragamnya tema konten yang diunggah, maka peneliti memberikan batasan pada lingkungan yang diteliti. Peneliti membatasi tahun lingkungan yang diteliti, yaitu unggahan dari Januari 2018 hingga Juni 2020 dengan fokus pada unggahan-unggahan CGM BSF yang berisi konten promosi acara Cap Go M eh saja.

\subsection{Hasil Penelitian}

\section{Aktivitas Lingkungan akun Instagram @ cgmbogor_fest}

\section{a. judul poto/caption}

Judul atau caption poto digunakan untuk memperkuat isi pesan yang ingin disampaikan. Pada Gambar 2 terdapat unggahan yang dilakukan oleh akun @cgmbogor_fest tanggal 10 Januari 2018 @cgmbogor_fest. Unggahan tersebut berupa poster Bogor Street Festival 2018. 
Gambar 2

Unggahan poto akun @cgmbogor_fest pada tahun 2018
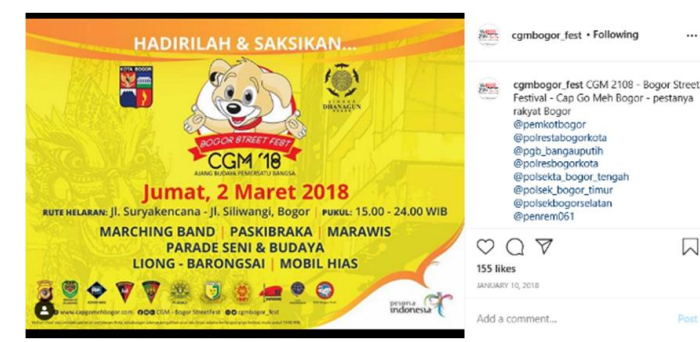

Sumber: akun @cgmbogor_fest

Pada poster tersebut terdapat keterangan tanggal, lokasi, serta pengisi acara Cap Go Meh 2018. Lalu terdapat caption yang bertuliskan 'CGM 2018-Bogor Street Festival-Cap Go Meh Bogor-pestanya rakyat Bogor'. Caption tersebut masih berkaitan dengan foto yang diunggah, namun tidak mendeskripsikan isi poster. Pengunggah hanya mengandalkan gambar/poster dalam menyampaikan pesan kepada pengikutnya.

Gambar 3

Unggahan poto akun @cgmbogor_fest pada tahun 2020

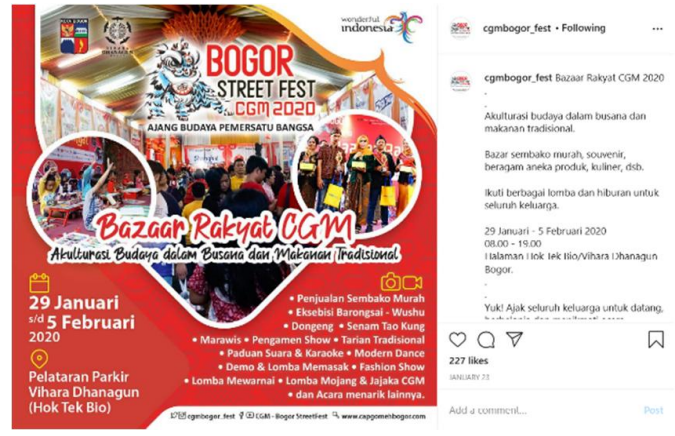

Sumber: akun @cgmbogor_fest

Pada tanggal 2 Februari 2020, akun @cgmbogor_fest mengunggah foto poster Bazar Rakyat Bogor Street Festival 2020. Pada poster tersebut terdapat judul poster, tanggal, lokasi, produk yang dipamerkan, serta akun media sosial 
yang dapat dihubungi. Caption mendukung gambar dengan memberikan beberapa produk yang dipamerkan, serta ada waktu dan tempat acara untuk menginformasikan pembaca.

\section{b. hasgtag}

Hashtag merupakan salah satu item yang terdapat di Instagram, yang diwakili tanda pagar (\#). Fungsinya adalah untuk menspesifikasikan topik/tema dalam Instagram serta memudahkan pengguna lain untuk mencari topik/tema yang berkaitan.

\section{Gambar 4}

Hashtag yang digunakan akun @ cgmbogor_fest pada tahun 2018

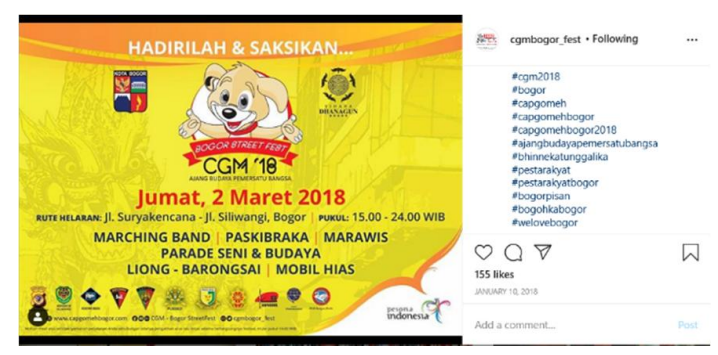

Sumber: akun @cgmbogor_fest

Akun Instagram @cgmbogor_fest menggunakan hashtag agar followers-nya mudah dalam mencari topik/tema seperti pada gambar 4 yang merupakan unggahan pada 10 Januari 2018. Saat itu @cgmbogor_fest mengunggah poto poster Bogor Street Festival 2018. Terdapat setidaknya leboh dari 10 hashtag yang tercantum, diantaranya \#cgm2018, \#bogor, \#capgomeh, \#apgomehbogor, \#capgomehn. Hashtag yang ada pada unggahan tersebut sudah relevan untuk memenuhi kebutuhan promosi. 


\section{Gambar 5}

Hashtag yang digunakan akun @cgmbogor_fest pada tahun 2020

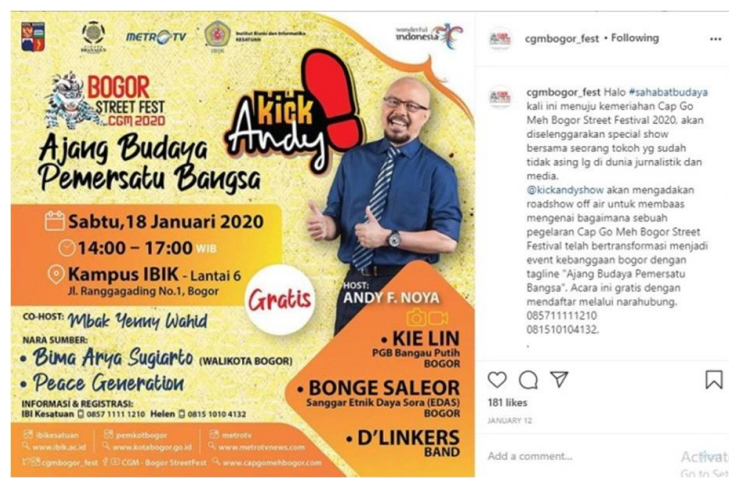

Sumber: akun @cgmbogor_fest

Pada 2020, akun @cgmbogor_fest juga masih menggunakan hashtag untuk membantu mempromosikan acara festival Cap Go Meh. Pada unggahan yang dilakukan pada 12 Januari 2020 tersebut, penggunaan hashtag terdapat dalam caption. Selain itu, penggunaan hashtag pada unggahan tersebut juga dilakukan pada bagian terpisah di bawah caption yang dapat dilihat pada Gambar 5.

\section{c. Geotag/lokasi}

Geotag atau lokasi merupakan salah satu fitur yang terdapat di Instagram yang berfungsi untuk menampilkan lokasi pengambilan gambar dari poto atau video yang diunggah. Berdasarkan observasi yang dilakukan, diketahui bahwa untuk unggahan yang merupakan promosi festival Cap Go Meh, akun @cgmbogor_fest tidak pernah menggunakan geotag/lokasi. Penggunaan geotag/lokasi hanya pernah dilakukan satu kali pada unggahan yang di posting pada 7 Januari 2020 mengenai pelaksanaan audiensi yang dilakukan panitia CGMBSF dengan Walikota Bogor untuk membahas persiapan kegiatan Cap Go Meh Bogor Festival. 


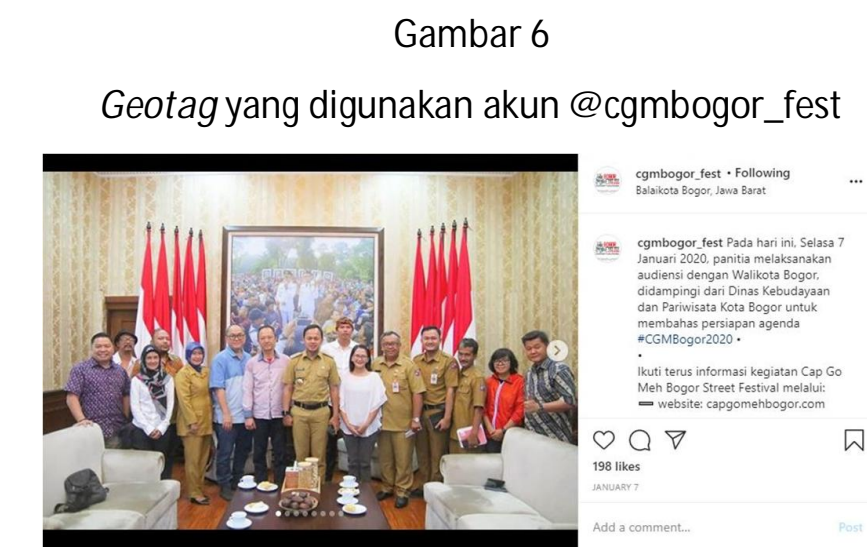

Sumber: akun @cgmbogor_fest

Pada Gambar 6 dapat dilihat penggunaan geotag/lokasi. Lokasi pada unggahan tersebut adalah Balaikota Bogor, Jawa barat. Unggahan ini ignin menegaskan bahwa panitia CGMBSF benar-benar berada di Balaikota, Bogor dan melakukan koordinasi dengan pemerintah kota Bogor pada kegiatan Cap Go Meh Bogor Street Festival.

\section{d. like}

Like merupakan salah satu fitur di Instagram untuk menyukai poto atau video yang diunggah. Like dapat dilakukan baik pada unggahan sendiri maupun unggahan orang lain. Penulis melakukan perhitungan dari total 70 unggahan akun @cgmbogor_fest dari Januari 2018- Juni 2020. Penulis mendata jumlah like tersebut ke dalam excel. Berdasarkan penghitungan dengan bantuan rumus average, diketahui bahwa dari dua unggahan promosi pada tahun 2018 rata-rata like-nya adalah 266,3. Pada tahun 2019 terdapat 54 postingan yang bersifat promosi dengan rata-rata 179,5. Kemudian pada tahun 2020 terdapat 14 postingan yang bersifat promosi dengan rata-rata 112,4.

Berdasarkan data tersebut diketahui bahwa unggahan promosi pada tahun 2019 memiliki rata-rata lebih tinggi jika dibandingkan dengan tahun 2018 dan 2020. Hal ini merupakan hal yang wajar dikarenakan jumlah unggahan dengan 
konten promosi pada tahun 2019 lebih banyak dibandingkan tahun 2018 dan 2020. Begitupun sebaliknya, rata-rata like 2018 merupakan rata-rata like terendah dibandingkan tahun 2019 dan 2020. Hal ini dikarenakan pada tahun 2018 panitia CGM BSF hanya mengunggah 2 konten promosi.

Rata-rata like Januari 2018 hingga Juni 2020 dapat dilihat pada grafik 1 berikut ini:

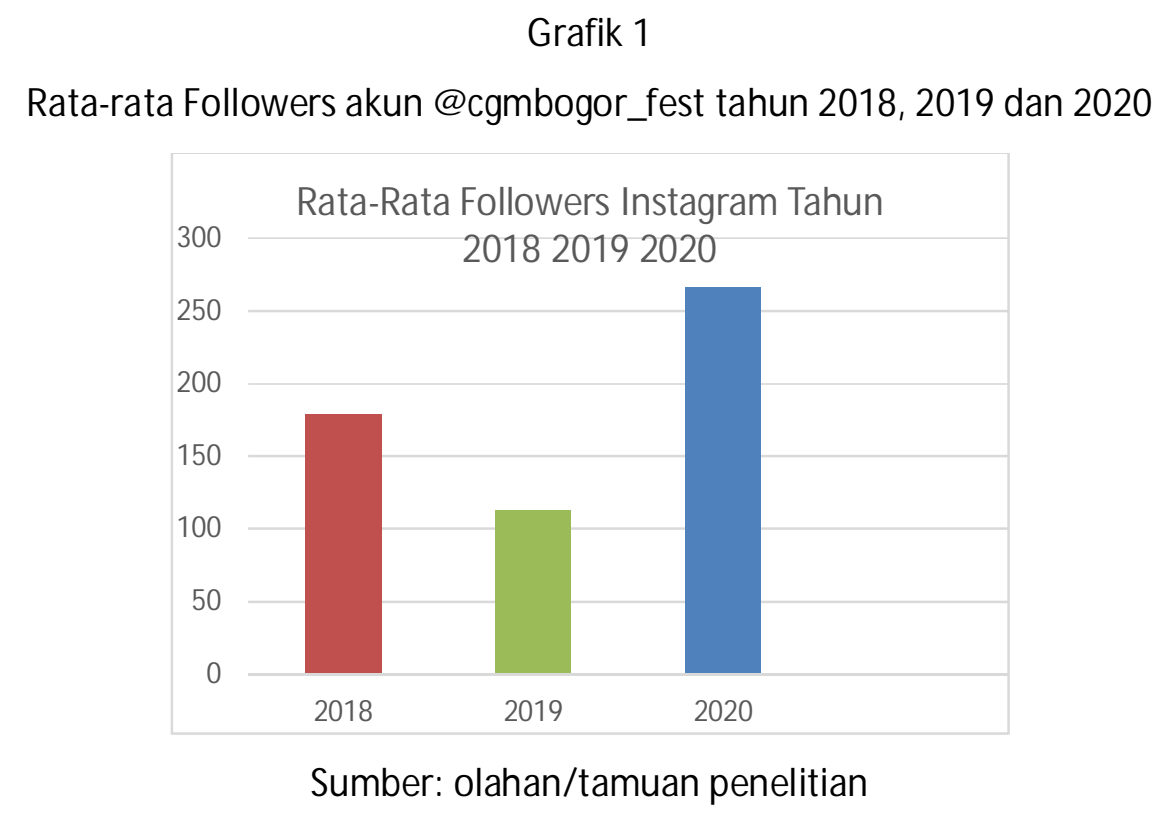

e. comment

Peneliti juga mengamati kolom komentar yang terdapat pada akun @cgmbogor_fest. Pada tanggal 4 Februari 2019, akun @cgmbogor_fest mengunggah poster Bogor Street Festival 2019. Unggahan poster tersebut mendapat tanggapan berupa komentar dari para followers akun ini. 


\section{Gambar 7 \\ Comment yang terdapat akun @cgmbogor_fest}
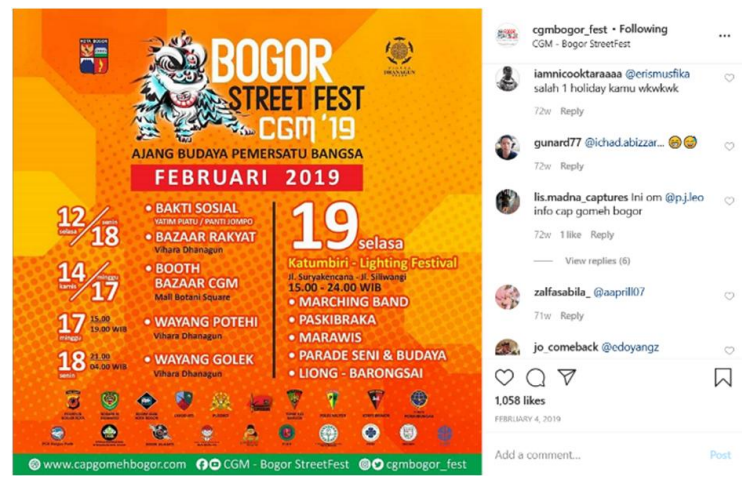

Sumber: akun @cgmbogor_fest

Pada unggahan poster tersebut terdapat sebanyak 59 komentar yang berisi pertanyaan tentang acara dan informasi, serta beberapa followers yang melakukan mention atas akun orang lain (teman, keluarga atau kolega) untuk diajak melihat poster tersebut. Komentar-komentar tersebut ada yang bertujuan untuk menginformasikan kepada followers atau akun lainnya atau juga bertanya dan mengemukakan opini tentang acara serta dukungan terhadap acara tersebut.

\section{f. Mention}

Tanggal 23 Januari 2020, akun @cgmbogor_fest mengunggah poster Bazar Rakyat CGM. Pada poster tersebut melakukan mention pada caption terhadap akun @henrimci4 sebagai bintang tamu dalam acara tersebut. Berikut mention yang terdapat pada caption akun @ cgmbogor_fest. 
Gambar 8

Mentiont yang terdapat akun @cgmbogor_fest

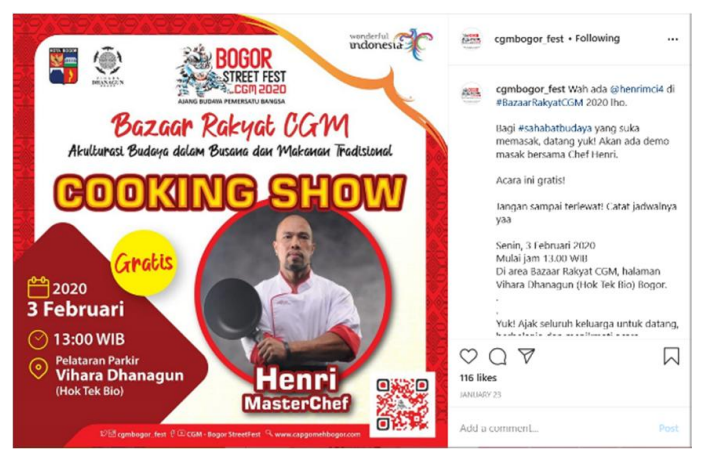

Sumber: akun @cgmbogor_fest

\section{Bentuk Promosi Festival Cap Go Meh oleh akun Instagram @ cgmbogor_fest}

Hasil pengamatan yang dilakukan diketahui bahwa terdapat empat bentuk promosi festival Cap Go M eh yang dilakukan oleh panitia CGM BGF melalui akun @ cgmbogor_fest, yaitu dengan menggunakan poster digital, poto, video promosi dan potongan poto.

\section{a. Poster Digital}

Poster digital digunakan oleh panitia CGMBSF untuk mempromosikan acara Cap Go Meh Bogor Street Festival. Berdasarkan observasi yang dilakukan terhadap akun Instagram @cgmbogor_fest diketahui bahwa terdapat dua poster promosi acara Cap Go Meh Bogor Street Festival pada tahun 2018. Pada tahun 2019 terdapat 4 poster promosi. Pada tahun 2020 terdapat 8 promosi. 


\author{
Gambar 9 \\ Poster digital promosi Cap Go M eh Bogor Street Festival 2020
}

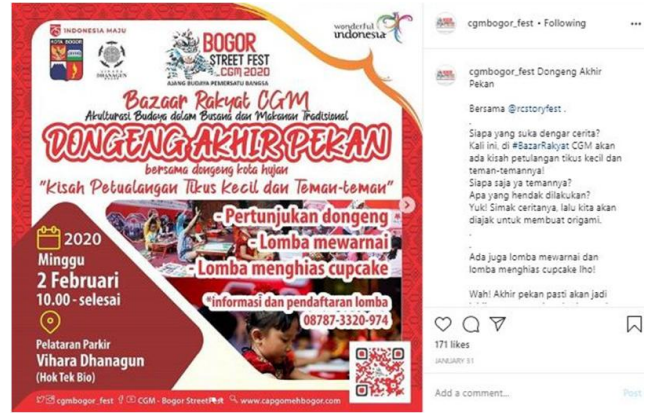

Sumber: akun @cgmbogor_fest

Gambar 9 merupakan salah satu poster promosi yang diunggah oleh akun @cgmbogor_fest. Poster tersebut berisi tentang acara dongeng, lomba mewarnai dan menghias cupcake yang merupakan rangkaian acara Cap Go M eh Bogor Street Festival 2020. Banyaknya poster yang diunggah pada promosi tahun 2020 dikarenakan banyak dan beragamnya rangkaian acara yang diselenggarakan pada Cap Go M eh Bogor Street Festival diantaranya acara talkshow, pameran poto, bazar, dongeng, dan cooking show.

\title{
b. Poto
}

Selain poster digital, digunakan pula poto untuk mempromosikan Cap Go Meh Bogor Street Festival. Pada tahun 2019 diketahui bahwa akun @ cgmbogor_fest mengunggah lebih dari sepuluh poto untuk promosi Cap Go Meh Bogor Street Festival. Poto yang digunakan adalah poto kegiatan Cap Go Meh Bogor Street Festival tahun sebelumnya, yaitu tahun 2018. 
Gambar 10

Poto promosi Cap Go Meh Bogor Street Festival 2019

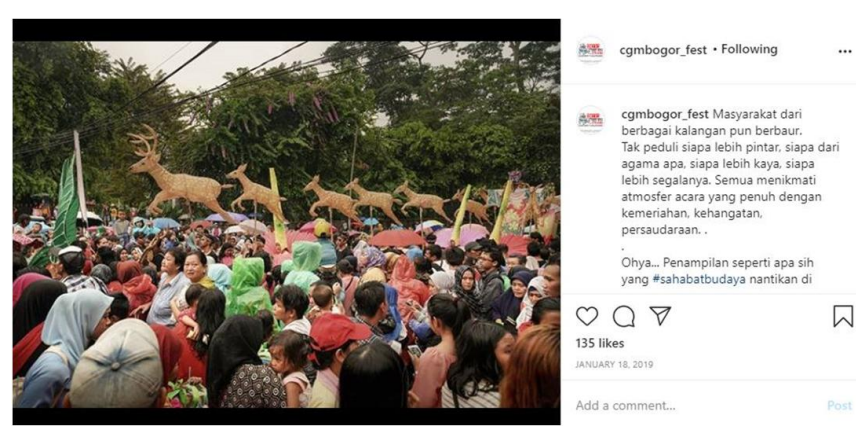

Sumber: akun @cgmbogor_fest

Pada Gambar 10 terdapat salah satu unggahan poto untuk promosi Cap Go Meh Bogor Street Festival. Poto tersebut menampilkan ramainya masyarakat yang hadir pada Cap Go Meh Bogor Street Festival. Pada caption tersebut merupakan poto promosi karena menampilkan panitia melalui poto tersebut dengan mengajak followers dari etnis mana saja dan kalangan apapun untuk hadir dalam festival tersebut.

\section{c. Video Promosi}

Promosi lainnya yang dilakukan oleh panitia CGMBSF melalui akun @ cgmbogor_fest adalah dengan mengunggah video promosi Cap Go M eh Bogor Street Festival pada tahun 2019 dan 2020. Pada tahun 2019, akun ini mengunggah 13 video promosi, sedangkan pada tahun 2020 hanya menguggah video promosi. Video promosi tersebut menampilkan orang-orang terkenal seperti artis, seniman, pejabat pemerintahan dan Kota Bogor, bahkan pihak kepolisian untuk mengajak followers hadir pada Cap Go Meh Bogor Street Festival. 


\section{Gambar 11}

Video promosi Cap Go M eh Bogor Street Festival 2019

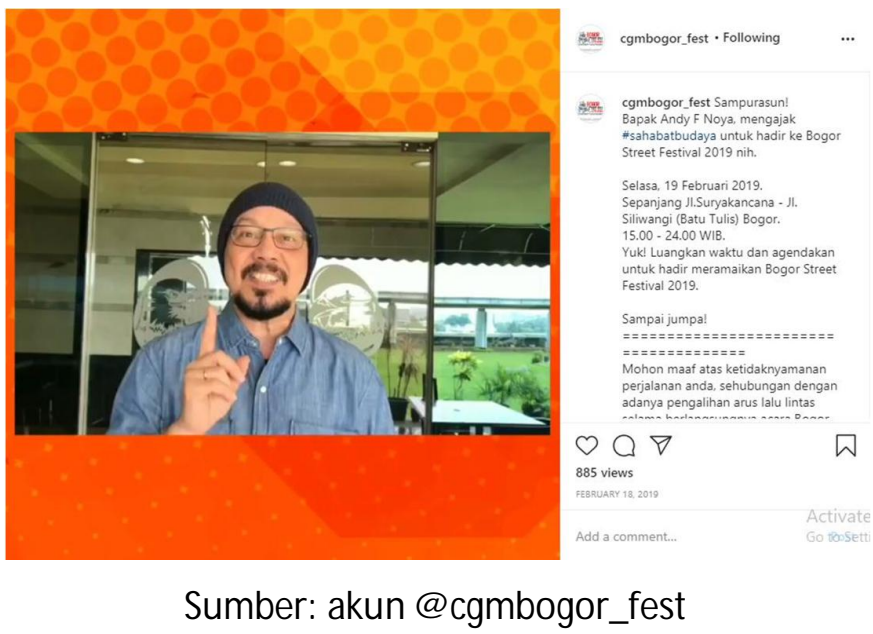

Gambar 11 merupakan salah satu video promosi yang menampilkan Andi F Noya, seorang host terkenal yang membawakan acara Kick Andi di Metro TV. Pada video tersebut, Andi menghimbau masyarakat untuk datang ke Kota Bogor dan menyaksikan secara langsung Cap Go M eh Bogor Street Festival 2019.

\section{d. Potongan Poto}

Selain poster, poto dan video, panitia CGMBSF juga menggunakan potongan poto dalam mempromosikan Cap Go Meh Bogor Street Festival. Tahun 2018 panitia tidak menggunakan potongan poto sebagai bagian promosi. Baru pada tahun 2019 panitian CGMBSF menggunakan potongan poto sebagai promosi. Panitia mengunggah sejumlah potongan poto yang kemudian dapat membentuk satu poto besar dari potongan poto tersebut. 


\section{Gambar 12}

Potongan Poto promosi Cap Go M eh Bogor Street Festival 2019
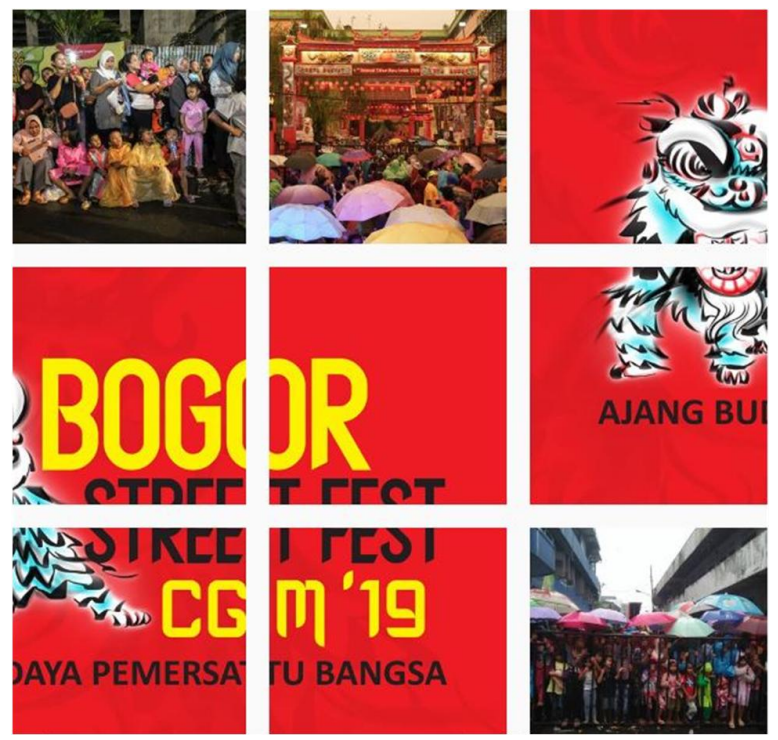

Sumber: akun @cgmbogor_fest

Salah satu contoh potongan poto yang diunggah akun @cgmbogor_fest dapat dilihat pada gambar 12. Pada gambar tersebut memperlihatkan potongan gambar berwarna merah yang jika disatukan menjadi sebuah poster Bogor Street Festival 2019.

\subsection{Pembahasan}

Perayaan Cap Go M eh di kota Bogor pertama kali dirayakan pada abad ke-16 sejak komunitas Tionghoa di Buitenzorg (nama Bogor kala itu) membangun Klenteng Hok tek Bio di Bogor. Masa jaya Cap Go Meh terjadi pada tahun 1954. Pada saat itu Presiden Soekarno mendundang arak-arakan Topekong dan Ceng G eke Istana Bogor untuk menghibur tamu negara. Pada 2008 diselenggarakan festival Cap Go M eh untuk pertama kalinya di kota Bogor. Acara itu masuk dalam agenda festival kota Bogor dengan tema pesta budaya Bogor. 
Festival Cap Go Meh di Kota Bogor semakin lama mengalami banyak perkembangan, diantaranta dari sisi pengisi acara dan jumlah masyarakat yang datang untuk menonton. Pada 2007 acara ini mendapatkan rekor dari Musium Rekor Indonesia (MURI) karena memiliki jumlah liong dan barongsai terbanyak. Selanjutnya kembali mendapatkan rekor MURI lagi dengan prestasi liong terpanjang, yaitu sepanjang 15 meter dengan 15 orang pemain.

Banyaknya prestasi yang dimiliki dan ramainya animo dari masyarakat membuat festival ini mendapatkan perhatian dari Provinsi Jawa Barat dan Kementrian Pariwisata. Presiden Jokowi pun pernah menghadiri acara ini pada Cap Go M eh tahun 2015. Suatu kebanggaan untuk panitia penyelenggara karena Presiden pada saat itu datang sebagai sebuah kejutan.

Festival ini merupakan bentuk akulturasi budaya yang tidak hanya menampilkan kebudayaan khas Tionghoa dan Sunda saja, akan tetapi juga menampilkan kebudayaan dari etnis lainnya. Pada tahun 2014 festival ini menampilkan berbagai macam kesenian khas dari kebuayaan Nusantara dan termasuk dalam agenda promosi nasional.

Animo masyarakat terhadap festival ini tergolong tinggi namun pihak panitia merasa perlu untuk melakukan promosi. Salah satu promosi yang dilakukan oleh pihak panitia CGMBSF adalah melalui media sosial, yaitu Facebook, Instagram, Twitter, Website, dan Youtube. Instagram merupakan akun media sosial milik panitia CGMBSF yang paling aktif jika dibandingkan empat akum media sosial lainnya.

Melalui akun Instagram @cgmbogor_fest, panitia menggunakan empat bentuk promosi, yaitu melalui unggahan poster digital, poto, video dan potongan poto. Keempat bentuk promosi ini masing-masing memiliki kekuatan tersendiri. Poster digital merupakan bentuk promosi utama yang digunakan oleh panitia CGM BSF karena di dalam poster terdapat informasi terkait penyelenggaraan Cap Go Meh Bogor Street Festival. Poto sebagai bentuk promosi didukung dengan caption karena poto yang digunakan merupakan bentuk promosi yang dilakukan 
secara halus atau soft promotion dengan secara tidak langsung membujuk followers untuk hadir dalam acara tersebut. Caption berfungsi menjelaskan maksud dari unggahan poto tersebut yang merupakan ajakan atau mengandung unsur persuasi. Panitian CGMBSF juga menggunakan video untuk promosi acara ini dengan menampilkan orang-orang terkenal untuk membujuk followers agar datang menyaksikan langsung. Video juga dibantu dengan caption yang memberikan informasi mengenai nama orang dalam video tersebut serta waktu dan tempat pelaksaan acara. Bentuk promosi terakhir yaitu dengan menggunakan potongan poto. Bentuk promosi ini jarang digunakan oleh panitia CGM BSF. Total hanya terdapat 2 poto yang digunakan sebagai bentuk promosi acara ini.

Keempat bentuk promosi tesebut merupakan upaya yang telah dilakukan oleh panitia CGMBSF selama tiga tahun terakhir di akun Instagram @cgmbogor_fest. Saat ini promosi pariwisata digital melalui media sosial sering dipergunakan baik untuk mempromosikan keindahan alam pada suatu daerah (Fauziah, et al 2018), wisata kuliner (Ayutiani \& Putri 2018) serta festival pariwisata (Satvikadewi \& Hamim 2018). Tujuan promosi pariwisata adalah untuk meningkatkan jumlah pengunjung pariwisata yang dipromosikan. Bentuk-bentuk promosi konvensional seperti poster yang ditempel di tempat-tempat umum, pamflet serta flyer yang dibagikan sudah dianggap tidak ef ektif dilakukan saat ini. Terlebih jika dilihat dari segi biaya. Promosi menggunakan media konvensional membutuhkan biaya yang besar. Dari segi waktu pun promosi dengan menggunakan media konvensional lebih lamban. Maka saat ini digunakanlah promosi pariwisata secara digital dengan menggunakan media sosial.

Cara-cara konvensional masih digunakan pada promosi melalui media sosial, yaitu dengan menggunakan poster. Akan tetapi poster yang digunakan adalah poster digital yang diunggah di media sosial. Cara konvensional lainnya adalah dengan menggunakan video. Akan tetapi video promosi tidak disiarkan melalui televisi, melainkan diunggah ke akun media sosial. Media sosial dapat 
mendistribusikan pesan dengan waktu yang lebih cepat serta biaya yang sangat minim. Poster digital tidak perlu dicetak seperti poster yang biasa ditempel di tempat umum. Ruang digital atau ruang mayalah yang menjadi tempat umumnya. Masyarakat yang membaca poster adalah masyarakat maya yang merupakan followers atau pengikut dari akun media sosial pribadi. Video promosi tidak perlu disiarkan di stasiun televisi dengan membayar sejumlah uang. Penontonnya adalah masyarakat maya yang menjadi followers akun media sosial.

Proses promosi patiwisata melalui media sosial yang dilakukan saat ini merupakan bagian dari implementasi Teori Computer M ediated Computer (CMC) yaitu komunikasi yang terjadi diantara dua individu atau lebih yang dimediasi oleh komputer (McQuail 2005). Telah terjadi perubahan bentuk pada proses promosi pariwisata melalui media sosial ini, yang tadinya dilakukan secara tradisional atau menggunakan media mainstream serta tatap muka, kini dapat dilakukan dengan medium sosial media pada telepon pintar sebagai perantaranya.

Berdasarkan penelitian yang dilakukan oleh Nurrahman \& Yuliati (2019) diketahui bahwa Instagram yang termediasi perangkat komputer efektif dalam mempromosi pariwisata. Hal ini disebabkan Instagram memiliki fitur-fitur yang dapat dipergunakan untuk menyampaikan informasi terkait promosi pariwisata untuk disampaikan kepada folllowers. Pemilihan Instagram sebagai media sosial untuk mempromosikan Instagram sudah tepat jika dikelola secara optimal.

\section{Simpulan}

Berdasarkan temuan penelitian ini diketahui bahwa akun @cgmbogor_fest melakukan empat bentuk promosi digital yaitu poster digital, poto, video dan potongan poto. Keempat bentuk promosi ini merupakan upaya yang dilakukan panitian CGMBSF agar masyarakat mengetahui adanya festival ini dan mau datang untuk melihat secara langsung. Diharapkan panitian CGM BSF dapat lebih 
optimal lagi dalam melakukan promosi melalui Instagram untuk mempromosikan acara ini dengan menggunakan fitur-fitur yang terapat dalam Instagram. Pada penelitian selanjutnya, dapat melakukan wawancara dengan pihak panitia untuk mengetahui strategi komunikasi yang dilakukan dalam mempromosikan festival Cap Go M eh kota Bogor.

\section{Daftar Pustaka}

Arnus, S.H. (2015). Computer Mediated Communication (CMC), pola baru berkomunikasi. Jurnal Al-M unzir Vol. 8, No. 2, 275-289.

Atiko, G., Ratih Hasanah Sudrajat, Kharisma Nasionalita. (2016). Analisis Strategi Promosi Pariwisata Melalui Media Sosial Oleh Kementerian Pariwisata RI (Studi Deskriptif Pada Akun Instagram @ Indtravel). Jurnal Sosioteknologi, Vol. 15, No 3, hal. 378-389.

Atmoko, D.B. (2018). Instagram Handbook. Jakarta. M edia Kita.

Araujo, CS., Correa. LPD., da Silva, APC., Prates, RO., \& M eira, W. (2014). It's is not just a pictue: Revealing some user practice in Instagram. In: Web Cpngress (LA-WEB), $20149^{\text {th }}$ Latin American, Ouro Preto, IEEE, Brazil, pp. 1923.

Ayutiani, D. N., \& Satria Putri, B.P. (2018). Penggunaan Akun Instagram Sebagai Media Informasi Wisata Kuliner. PRofesi Humas: Jurnal IImiah IImu Hubungan Masyarakat, 3(1), 39. https://doi.org/10.24198/prh.v3i1.11683

Budiargo, D. (2015). Berkomunikasi Ala Net Generation. Elex Media Komputindo. Jakarta.

Bungin, Burhan. (2015). Komunikasi Pariwisata: Pemasaran dan Brand Destinasi. Jakarta. Kencana Prenada M edia Group.

Cangara, H. (2016). Pengantar Ilmu Komunikasi. Jakarta. Raja Grafindo Persada.

Fatanti, M. N., \& Suyadnya, I. W. (2015). Beyond User Gaze: How Instagram Creates Tourism Destination Brand? Procedia - Social and Behavioral Sciences, 211, 1089-1095. http:// doi.org/10.1016/j.sbspro.2015.11.145.

Fauziah, R., Ike Atikah Ratnamulyani, \& Ali Alamsyah Kusumadinata. (2018). Efektifitas Promosi Destinasi Wisata Rekreasi Gunung Pancar Melalui Postingan Instagram Media Sosial. Jurnal Komunikatio, Vol. 4, No. 1, hal. 2740.

Gohil, Neeraj (2015). Role and Impact of Social Media in Tourism: A Case Study on the Initiatives of $M$ adhya Pradesh State Tourism. International Journal of Research in Economics and Social Sciences, Vol. 5, No. 4, hal. 8-15.

Hiltz, S`R. \& Turoff, M. (1978). The network nation: Human communication via computer. Cambridge, Mass. MIT Press.

Hine, C. (2000). Virtual Ethnography. London: Sage Publication Ltd. 
Kertamukti, R. (2015). Instagram dan Pembentukan Citra (Studi Kualitatif Komunikasi Visual dalam Pembentukan Personal Karakter Account Instagram @ Basukibtp). Jurnal Profetik, Vol. 8, No. 1, hal. 57-66.

Kozinets, R.V. (2013). Netnography Doing Etnographic Research Online. Washington, DC: Sage Publication Ltd.

Kurniawati, WDN. (2016). Pemanfaatan Instagram oleh Komunitas Wisata Grobogan dalam Mempromosikan Potensi Pariwisata Daerah. Komuniti, VIII(2), pp. 127-144. journals.ums.ac.id/index.php/ komuniti/article/download/2943/2443.

M cQuail, D. (2005). M cQuail's Mass Communication Theory. Thousand Oaks.

Nasrullah, Ruli. (2017). Etnografi Virtual: Riset Komunikasi, Budaya, dan Sosioteknologi di Internet. Bandung: Simbiosa Rekatama M edia.

Nurjanah. (2018). Pemanfaatan media sosial masyarakat sadar wisata dalam mempromosikan potensi wisata baru. Jurnal Medium, Vol. 6 No. 2, hal. 239-50.

Nurrahman, R. \& Yuliati. (2019). Efektivitas media sosial instagram @ visitbengkulu sebagai media promosi pariwisata Provinsi Bengkulu. Jurnal Kaganga, Vol. 3(1), 25-36.

Pendit. S.N. (1999). Ilmu Pariwisata Sebuah Pengantar Perdana. Jakarta: Pradnya Paramita.

Prastika, AC. (2017). Gerakan Sosial Baru di Dunia Siber. Etnografi Online M edia Sosial dalam Akun Twitter dan Halaman Facebook Gerakan Yogya Darurat Agraria. [Skripsi]. Universitas Gadjah Mada. Yogyakarta.

Pratiwi, A., Sarwititi S., Endriatmo S., Nurmala P. $\left(2019^{2}\right)$. Strategi Komunikasi Gerakan Perlawanan Petani di Media Sosial (Studi Etnografi Virtual pada akun Instagram @jogja_darurat_agraria) [Communication Strategy of Farmer Resistance M ovement in Social M edia (Virtual Ethnographic Study on Instagram account @jogja_darurat_agraria)]. Jurnal Pekommas, Vol 4(2):165-176.

Purnomo, A. (2018). Pemanfaatan instagram sebagai media komunikasi pariwisata di kabupaten karanganyar (studi analisis deskriptif kualitatif pada akun instagram @explorekabkaranganyar). [Skripsi]. Universitas Muhammadiyah Surakarta. Surakarta [ID].

Ri'aeni, I. (2015). Penggunaan New M edia dalam Prom osi Pariwisata Daerah Situs Cagar Budaya di Indonesia. Jurnal Komunikasi, Vol. 9(2), 187-197.

Retnasary, M., Dewi Setiawati, S., Fitriawati, D., \& Anggara, R. (2019). Pengelolaan Media Sosial Sebagai Strategi Digital Marketing Pariwisata. Jurnal Kajian Pariwisata, 1(1), 76-83. http://ejurnal.ars.ac.id/index.php/JIIP/article/view/130

Santoso, D.H. (2014). Mobilisasi Sosial dalam Ruang Virtual: Studi Etnografi Virtual pada Situs www.sedekahrombongan.com. Jurnal Pekommas, Vol. 17, No. 1. 
Satvikadewi, A.A.I.P., \& Hamim. (2018). Pemanfaatan Media Sosial Sebagai Strategi Komunikasi Untuk Mempromosikan Potensi Lokal Wisata Pulau Bawean. Seminar Hasil Penelitian dan Pengabdian Masyarakat "Hasil Riset dan Pengabdian Masyarakat Sebagai Inovasi Menuju Persaingan Global", Vol. 1, No. 1.

Soekadijo. R.G. (2000). Anatomi Pariwisata, Memahami Pariwisata Sebagai Sistematic Linkage. Jakarta. Gramedia Pustaka Utama.

Sugiarto, M. (2018). Instagram M arketing: 3 cara cara sistematis mengumpulkan follower permanen di instagram dan membuat mereka menjadi membeli dari anda. Surabaya. Gramedia

Sukoco, A. (2017). Pemanfaatan Instagram sebagai media Promosi Wisata kebun Buah Mangunan (Studi Deskriptif Kualitatif pada Akun Instagram @ kebunbuahmangunanbantul). [Skripsi]. Universitas Islam negeri Yogyakarta [ID].

Suryadana, Liga M \& Octavia, Vanny. (2015). Pengantar Pemasaran Pariwisata. Bandung. Alfabeta.

Ting, T.C. (2014). A study of motives, usage, self-presentation and number of followers on instagram. Discovery - SS Student E-Journal, Vol. 3, p. 1-35.

Trihayuningtyas, E., W. Wulandari., Y. Adriani, I.A.M .P., Sarasvati. (2018) M edia sosial sebagai sarana informasi dan promosi pariwisata bagi generasi $Z$ di Kabupaten Garut. Tourism Scientific Journal. Vol. 4, No. 1, hal. 1-22.

Wati, L. dan Robi Setiawan. (2019). Dramaturgi content creator dalam presentasi diri di instagram (Studi Etnografi Virtual Pada Akun Instagram @ Bangijal_Tv). Jurnal Dialektika Komunikas, Vol. 7, No. 2, hal. 12-21.

Witri, A.A., \& Mutia Rahmi Pratiwi. (2019). Etnografi Virtual Pada Laman Pengguna Instagram Stories (IG Stories) Sebagai Bentuk Komunikasi Interpersonal. Jurnal Audience, Vol 02 No. 02, hal. 135-154.

Yoeti, O.A. (1996). Pengantar Ilmu Pariwisata. Bandung. Angkasa.

\section{Sumber Internet:}

http://bersabda.com/daya-saing-pariwisata-indonesia-urutan-42-dari-136-negaradi-dunia-di-tahun-2017/

Harto, A. (2014). "Pesta Rakyat Bogor untuk Persatuan dan Kesatuan". Kompas.com. https://travel.kompas.com/ read/2014/02/15/1107558/Pesta.R akyat.Bogor.untuk.Persatuan.dan. Kesatuan?page=2.

https://www.marketingcharts.com/digital/social-media-108463 